PRACE GEOGRAFICZNE

zeszyt 153, 2018, 89-103

doi: $10.4467 / 20833113$ PG.18.005.8480

Instytut Geografii i Gospodarki Przestrzennej UJ

Wydawnictwo Uniwersytetu Jagiellońskiego

\title{
OCENA WARUNKÓW BIOKLIMATYCZNYCH POLSKI WSCHODNIEJ DO WYBRANYCH FORM REKREACJI I TURYSTYKI
}

\author{
Sylwester Wereski, Mateusz Dobek, Karolina Kierklo
}

\section{Evaluation of bioclimatic conditions for selected forms of recreation and tourism in Eastern Poland}

Abstract: In this paper authors present an evaluation of bioclimatic conditions in the eastern part of Poland in regard to selected forms of recreation and tourism. For this purpose the biothermal-meteorological weather classification by K. Błażejczyk was used. Meteorological data for the period 1981-2015 were obtained from the Institute of Meteorology and Water Management meteorological stations at Białystok, Lublin-Radawiec and Lesko. It was found that in Eastern Poland the most favourable conditions for sunbathing (SB) and aerotherapy $(\mathrm{AB})$ occur from mid-April to mid-October, but in Lesko better conditions for these recreation types are more frequent during the autumn moths. As for mild forms of recreation (MR) weather conditions are favourable more often during the year in Lesko than in Lublin or Białystok. As for intense activity (AR), favourable weather conditions occur during most days of the year. The type of recreation favoured by weather conditions in Eastern Poland for the shortest period of the year is ski tourism (ST). In Lublin and Białystok this period lasts from the beginning of February to the first decade of March. In Lesko the ski tourism season begins at the end of December and it is twice as long as in the other stations.

Keywords: Eastern Poland, bioclimate assessment index weather, WSI, biothermal-meteorological weather classification

Zarys treści: W pracy dokonano oceny warunków bioklimatycznych Polski Wschodniej pod kątem możliwości uprawiania wybranych form rekreacji i turystyki. W tym celu wykorzystano 
biotermiczno-meteorologiczną klasyfikację pogody K. Błażejczyka. Analiza warunków pogodowych, dla wybranych form rekreacji turystyki, została opracowana na podstawie danych meteorologicznych pochodzących ze stacji IMGW-PIB: Białystok, Lublin-Radawiec oraz Lesko, za lata 1981-2015. Stwierdzono, że najkorzystniejsze warunki do helioterapii (SB) oraz aeroterapii $(\mathrm{AB})$ występują w Polsce Wschodniej od połowy kwietnia do połowy października. W obydwu przypadkach jesienią obserwowane jest uprzywilejowane położenie Leska w porównaniu z pozostałymi stacjami. Z punktu widzenia możliwości uprawiania łagodnych form rekreacji (MR) korzystne warunki atmosferyczne trwają od początku lutego do połowy października, a w Lesku do pierwszej dekady grudnia. Do uprawiania aktywnych form rekreacji ruchowej (AR) korzystne warunki pogodowe występują przez znaczną część roku, przy czym najrzadziej występują one w miesiącach letnich. We Wschodniej Polsce warunki pogodowe sprzyjają najkrócej turystyce narciarskiej (ST), przy czym w Lesku okres ten jest dwa razy dłuższy niż Lublinie i Białymstoku, gdzie rozpoczyna się na początku lutego i trwa do początku marca.

Stowa kluczowe: Polska Wschodnia, bioklimat, wskaźnik oceny pogody, WSI, biotermiczno-meteorologiczna klasyfikacja pogody

\section{Wstęp}

Obecnie turystyka jest jedną z najszybciej rozwijających się gałęzi gospodarki światowej, a dochody z niej stanowią ponad 9\% światowego PKB (7,2 bln USD w 2015 r.), zaś liczba osób zatrudnionych w tym sektorze wynosi $284 \mathrm{mln}$ (The World Travel \& Tourism Council 2016). Jak podaje Światowa Organizacja Turystyki, co roku liczba uczestników międzynarodowego ruchu turystycznego wzrasta i w 2015 r. wyniosła 1,2 mld osób (World Tourism Organiæation 2016). Poza aspektem gospodarczym turystyka odgrywa również bardzo ważną rolę w życiu człowieka, ponieważ zaspokaja potrzeby w zakresie poznawania otaczającego nas świata oraz umożliwia regenerację fizyczną i psychiczną organizmu.

Podejmując decyzję o wyborze miejsca wypoczynku, turysta powinien uwzględnić szereg elementów, do których należą m.in.: cechy środowiska przyrodniczego i kulturowego, a także stopień rozwoju i stan infrastruktury turystycznej. Jednym z elementów przyrodniczych, które w istotny sposób warunkują przebywanie człowieka w środowisku zewnętrznym, jest pogoda. Dlatego też ważne jest, by uczestnik ruchu turystycznego posiadał wiedzę o warunkach klimatycznych, a w szczególności bioklimatycznych obranego przez siebie celu podróży.

W ocenie warunków pogodowych, pod kątem możliwości uprawiania turystyki i rekreacji, należy uwzględnić cały zespół elementów meteorologicznych, do których należą m.in.: temperatura i wilgotność powietrza, prędkość wiatru, zachmurzenie, opad atmosferyczny i pokrywa śnieżna. Freitas (2001) wyróżnia trzy kategorie informacji ważnych dla osób przebywających w terenie otwartym: 
- termiczne, opisujące efekt łącznego działania temperatury i wilgotności powietrza, prędkości wiatru, natężenia promieniowania słonecznego oraz metabolicznej produkcji ciepła;

- fizyczne, mające istotny wpływ na przebywanie w środowisku zewnętrznym, w tym możliwość uprawiania wybranych form turystyki i rekreacji: opady deszczu, duże prędkości wiatru, pokrywa śnieżna, gołoledź, jakość powietrza atmosferycznego, promieniowanie UV;

- estetyczne, wpływające na wizualny odbiór otoczenia, w tym: usłonecznienie, zachmurzenie, widzialność oraz długość dnia.

W klimatologii jedną z metod pozwalających na opis warunków pogodowych jest klasyfikacja typów pogody. Pierwsze typologie, których autorami byli m.in. Fiedorow, (Zinkiewicz 1953; Piotrowicz 2010), Howe (1925), Nichols (1925), Switzer (1925), uwzględniały podstawowe charakterystyki elementów meteorologicznych, takie jak: temperatura i wilgotność powietrza, prędkość wiatru czy zachmurzenie. Dla obszaru Polski tego rodzaju typologię opisującą zarówno stosunki termiczne, nefologiczne, jak i opadowe stworzył Woś (1996, 1999). Wraz z rozwojem meteorologii oraz jej narzędzi badawczych zaczęto tworzyć klasyfikacje dla potrzeb lecznictwa uzdrowiskowego oraz turystyki, wykorzystując do opisu warunków biotermicznych wskaźniki biometeorologiczne (Kozłowska-Szczęsna i in. 1997). W Polsce jednym z pierwszych badaczy zajmujących się tą problematyką był Błażejczyk $(1979,1983,1992)$. Na podstawie wieloletnich badań i obserwacji poszczególne kompleksy pogodowe mogą być poddane ocenie jakościowej. Przykładem takiej waloryzacji jest wskaźnik WSI (Weather Suitability Index), którego wartości zostały wyznaczone w oparciu o biotermiczno-meteorologiczną klasyfikację pogody Błażejczyka (2004, 2005). Wskaźnik ten był wykorzystywany m.in. do oceny warunków pogodowych Warszawy (Błażejczyk 2005), Wrocławia (Sikora 2008), Soliny (Wereski 2012), Leska (Wereski, Demczuk 2015), a także Karkonoszy (Miszuk 2006, 2008) i otoczenia Jeziora Miedwie (Koźmiński i in. 2007). Natomiast Miszuk wraz z zespołem przedstawili dla Zgorzelca i Śnieżki, w oparciu o scenariusze zmian klimatu: A1B, RCP2.6, RCP8.5, prognozy zmian wartości wskaźnika WSI dla łagodnych form rekreacji w okresie 2021-2050 oraz 2071-2100 (Miszuk i in. 2016).

Celem niniejszej pracy jest określenie przydatności warunków pogodowych Polski Wschodniej pod kątem wybranych form rekreacji i turystyki, na podstawie wskaźnika oceny pogody (WSI avg $_{\text {) }}$ Przedstawione poniżej wyniki badań mogą stanowić źródło informacji podczas organizacji i planowania wypoczynku w tej części kraju. 


\section{Material i metody opracowania}

W pracy wykorzystano wyniki pomiarów i obserwacji z godziny 12 UTC (temperatura powietrza, wilgotność względna, zachmurzenie, prędkość wiatru) oraz dobowe wartości temperatury maksymalnej i minimalnej, sum opadów atmosferycznych i grubości pokrywy śnieżnej z trzech stacji IMGW-PIB: Białystok, Lublin-Radawiec oraz Lesko z okresu 1981-2015. Stacje te reprezentują różne regiony bioklimatyczne Polski Wschodniej.

Region północno-wschodni (III), na którego obszarze znajduje się stacja w Białymstoku, odznacza się największą liczbą dni uciążliwych pod względem niskich temperatur powietrza i dużych prędkości wiatru. W regionie południowo-wschodnim (V), na którym położona jest stacja Lublin-Radawiec, występuje 30-40\% dni w roku odznaczających się uciążliwymi warunkami związanymi z wysoką temperaturą powietrza. Natomiast region karpacki (VIII), ze stacją w Lesku, wyróżnia się dużą zmiennością przestrzenną i czasową warunków atmosferycznych wpływających obciążająco na organizm człowieka (Kozłowska-Szczęsna i in. 1997; Błażejczyk 2004).

Dla wyżej wymienionych stacji w programie Bioklima_2.6 dla każdego dnia zostały określone typy, podtypy i klasy pogody. Typ pogody scharakteryzowano na podstawie wskaźnika temperatury odczuwalnej (STI), podtypy pogody uwzględniały natężenie bodźców radiacyjnych, rodzaj stresu termofizjologicznego i natężenie odczucia parności, natomiast klasy pogody określono na podstawie dobowej amplitudy temperatury powietrza, sumy dobowej opadów oraz grubości pokrywy śnieżnej. Zapis warunków pogodowych ma postać siedmioelementowego kodu i został przedstawiony w pracach: Błażejczyka (2004, 2005) oraz Błażejczyka i Kunerta (2011).

Dla każdego dnia, w oparciu o typ, podtypy i klasy pogody, została określona wartość wskaźnika oceny pogody (WSI) dla różnych form aktywności: kąpieli słonecznych (SB), kąpieli powietrznych (AB), łagodnej rekreacji ruchowej (MR), intensywnej rekreacji ruchowej (AR), turystyki i rekreacji narciarskiej (ST). Wartość wskaźnika oceny pogody (WSI) została ustalona na podstawie wieloletnich badań termofizjologicznych prowadzonych przez autora klasyfikacji:

- WSI = 0, gdy warunki pogodowe są nieprzydatne dla danej formy aktywności;

- WSI = 1, gdy warunki pogodowe są przydatne z ograniczeniami dla danej formy aktywności;

- WSI = 3, gdy warunki pogodowe są przydatne bez ograniczeń dla danej formy aktywności.

Kolejnym krokiem było obliczenie, dla każdego dnia i każdej formy wypoczynku osobno, średniej dobowej wartości wskaźnika oceny pogody (WSI ${ }_{\text {avg }}$ ) z wielolecia. Pozwoliło to na określenie przydatności warunków bioklimatycznych dla wybranych form turystyki w przebiegu rocznym. Do tego celu została wykorzystana skala oceny, którą zamieszczono w tabeli 1. 
Tab. 1. Skala oceny przydatności warunków pogodowych do wybranych form wypoczynku na podstawie wskaźników WSI

Table 1. Scale of evaluation of the suitability of weather conditions for selected types of recreation based on the WSI $_{\text {avg }}$

\begin{tabular}{|c|c|}
\hline $\begin{array}{c}\text { Ocena przydatności pogody } \\
\text { Evaluation of the suitability of weather conditions }\end{array}$ & $\begin{array}{c}\text { Wartość wskaźnika WSI } \\
\text { Values of the WSI } \text { avg }_{\text {avg }} \text { index }\end{array}$ \\
\hline $\begin{array}{c}\text { pogoda niekorzystna } \\
\text { useless weather conditions }\end{array}$ & $0,00-0,49$ \\
\hline $\begin{array}{c}\text { pogoda umiarkowanie korzystna } \\
\text { moderately useful weather conditions }\end{array}$ & $0,50-1,19$ \\
\hline $\begin{array}{c}\text { pogoda korzystna } \\
\text { useful weather conditions }\end{array}$ & $1,20-1,99$ \\
\hline $\begin{array}{c}\text { pogoda bardzo korzystna } \\
\text { very useful weather conditions }\end{array}$ & $\geq 2,00$ \\
\hline
\end{tabular}

Źródto: Błażejczyk, Kunert 2011.

Source: Błażejczyk, Kunert 2011.

\section{Warunki bioklimatyczne a możliwość uprawiania wybranych form rekreacji i turystyki w Polsce Wschodniej}

\section{Biotermiczno-meteorologiczne typy pogody}

W latach 1981-2015 na analizowanych stacjach znajdujących się na obszarze Polski Wschodniej zanotowano odpowiednio: w Lesku - 159, w Lublinie - 157, w Białymstoku - 154 kompleksów pogodowych, stanowiących kombinację różnych typów, podtypów i klas pogody. W Lesku najczęściej występowała pogoda chłodna, o słabych bodźcach radiacyjnych, znacznym lub dużym natężeniu stresu zimna, z brakiem lub niewielkim stresem termiczno-wilgotnościowym, o małych kontrastach termicznych, z opadem atmosferycznym i pokrywą śnieżną o grubości, która nie przekraczała $10 \mathrm{~cm}$ lub z jej brakiem (-1_1C0_010). Ten kompleks pogodowy reprezentuje warunki pogodowe nieprzydatne zarówno dla kąpieli słonecznych, kąpieli powietrznych, jak i turystyki narciarskiej, a przydatne z ograniczeniami dla łagodnych i aktywnych form rekreacji. W analizowanym okresie kompleks ten obserwowano w Lesku z częstością 8,7\% dni, natomiast w Lublinie i w Białymstoku odpowiednio z częstością: 7,2 i $6,2 \%$ dni. W przebiegu rocznym na stacjach kompleks -1_1C0_010 występował we wszystkich miesiącach roku i był notowany najczęściej we wrześniu (Lublin i Lesko - odpowiednio 18,1\% i 16,6\% dni) oraz 


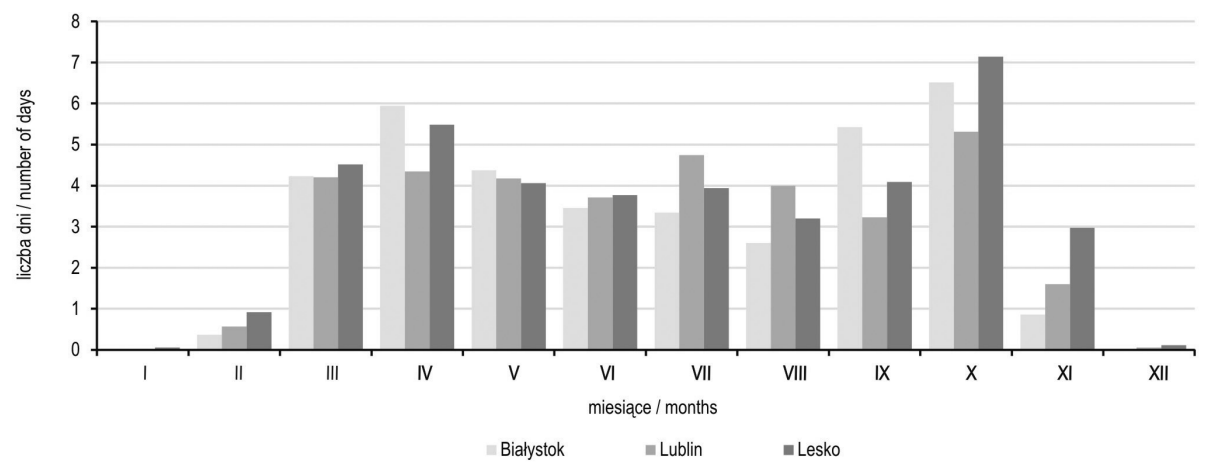

Ryc. 1. Przebieg roczny średniej liczby dni z typem pogody komfortowej w Polsce Wschodniej (1981-2015) na podstawie wskaźnika STI

Fig. 1. Annual diversity of the number of days with thermal comfort in Eastern Poland (1981-2015) based on the STI indice

w październiku (Białystok - 17,5\% dni). W Białymstoku i w Lublinie najczęściej obserwowano pogodę zimną, o słabych bodźcach radiacyjnych, znacznym lub dużym natężeniu stresu zimna, z brakiem lub niewielkim stresem termiczno-wilgotnościowym, o małych kontrastach termicznych, bez opadu atmosferycznego i z pokrywą śnieżną o grubości, która nie przekraczała $10 \mathrm{~cm}$ lub z jej brakiem (-2_1C0_000), odpowiednio z częstością 12,4\% i 12,1\%. W tym przypadku również warunki pogodowe są nieprzydatne dla kąpieli słonecznych, kąpieli powietrznych oraz turystyki narciarskiej, przydatne z ograniczeniami dla łagodnych form rekreacji, natomiast przydatne bez ograniczeń dla aktywnych form rekreacji. W Lesku frekwencja tego kompleksu wynosiła 7,2\%. Na analizowanych stacjach kompleks pogodowy -2_1C0_000 występował od października do kwietnia, z największą częstością w grudniu - odpowiednio w Lesku: 26,1\%, w Lublinie: 28,0\% i w Białymstoku: 28,8\% wszystkich dni.

\section{Komfort termiczny}

Z punktu widzenia funkcjonowania turystyki duże znaczenie ma liczba dni, podczas których występują warunki komfortu termicznego. Na podstawie wartości temperatury odczuwalnej (STI), wyznaczonej dla południowego terminu obserwacji, określono liczbę dni, podczas których występuje komfort termiczny. Najwięcej takich dni notowano w Lesku - średnio 40 dni w roku. W Lublinie i w Białymstoku było 
odpowiednio 36 i 37 takich dni. W poszczególnych latach na analizowanych stacjach Polski Wschodniej liczba dni z komfortem termicznym w południowym terminie obserwacji zmieniała się od 19 dni w 2013 r. w Białymstoku do 55 dni w 2014 r. w Lesku. W przebiegu rocznym dni takie występowały od lutego do listopada, przy czym pojedyncze przypadki notowano również w styczniu (2 dni w Lesku) i w grudniu (2 dni w Lublinie i 4 dni w Lesku). Najwięcej dni z komfortem cieplnym we wschodniej części Polski odnotowano w październiku - średnio od 5 dni w Lublinie do 7 dni w Lesku oraz w kwietniu - średnio od 4 dni w Lublinie do 6 dni w Białymstoku. Na uwagę zwraca sytuacja w Lublinie, gdzie średnia liczba dni z komfortem cieplnym w lipcu wynosiła 5 dni w miesiącu, podczas gdy w Białymstoku i Lesku dni takie występowały odpowiednio średnio 3 oraz 4 razy w miesiącu (ryc. 1).

\section{Kąpiele słoneczne (SB)}

Na podstawie wartości wskaźnika WSI ${ }_{\text {avg(SB) }}$ stwierdzono, że okres, w którym w Polsce Wschodniej warunki pogodowe sprzyjały korzystaniu z kąpieli słonecznych (SB) trwał od połowy kwietnia do połowy października (ryc. 2). Największą liczbą dni z warunkami korzystnymi i bardzo korzystnymi dla tej formy rekreacji odznaczał się maj (od 22 dni w Lesku do 29 dni w Białymstoku) oraz wrzesień (od 20 dni w Lublinie do 25 dni w Białymstoku). W Lesku duża liczba takich dni przypadała również na sierpień, a w Białymstoku na czerwiec - po 22 dni w miesiącu. Podczas dwóch miesięcy wiosennych, tj. w kwietniu i w maju, zaobserwowano uprzywilejowane położenie dla kąpieli słonecznych Białegostoku, gdzie w tym okresie notowano średnio 46 dni z pogodą korzystną i bardzo korzystną dla tej formy rekreacji. Z kolei podczas dwóch miesięcy jesiennych, tj. we wrześniu i w październiku, uprzywilejowane było położenie Leska, gdzie 36 dni oceniono pod względem warunków pogodowych jako korzystne i bardzo korzystne dla kąpieli słonecznych.

\section{Kąpiele powietrzne $(\mathrm{AB})$}

Podobnie jak w przypadku kąpieli słonecznych (SB) w Polsce Wschodniej okres, w którym warunki pogodowe są korzystne dla kąpieli powietrznych (AB), rozpoczynał się w połowie kwietnia i trwał do połowy października, a w Lesku nawet do końca tego miesiąca (ryc. 2). W analizowanych miastach powyżej 20 dni z pogodą sprzyjającą tej formie rekreacji (dni korzystne i bardzo korzystne) obserwowano od maja do września. Największa liczba takich dni przypadała w maju (26 dni w Lesku i po 30 dni w Lublinie i w Białymstoku) oraz w sierpniu (po 30 dni we wszystkich analizowanych miastach), a w Białymstoku również w lipcu (31 dni w miesiącu). W Lesku 20 dni korzystnych dla kąpieli powietrznych, dwukrotnie więcej niż w Lublinie i w Białymstoku, notowano również w październiku. 
Białystok

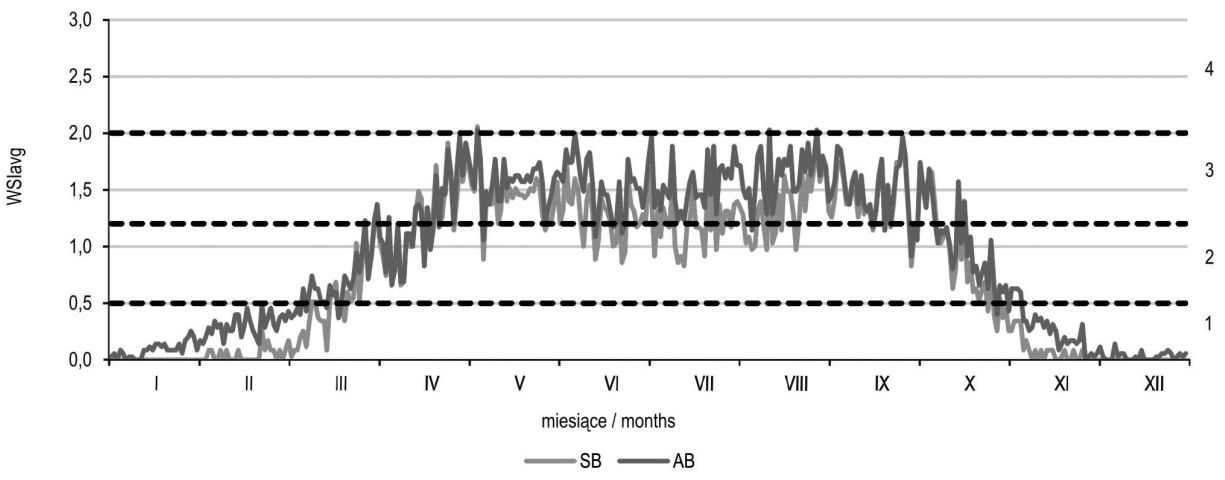

Lublin

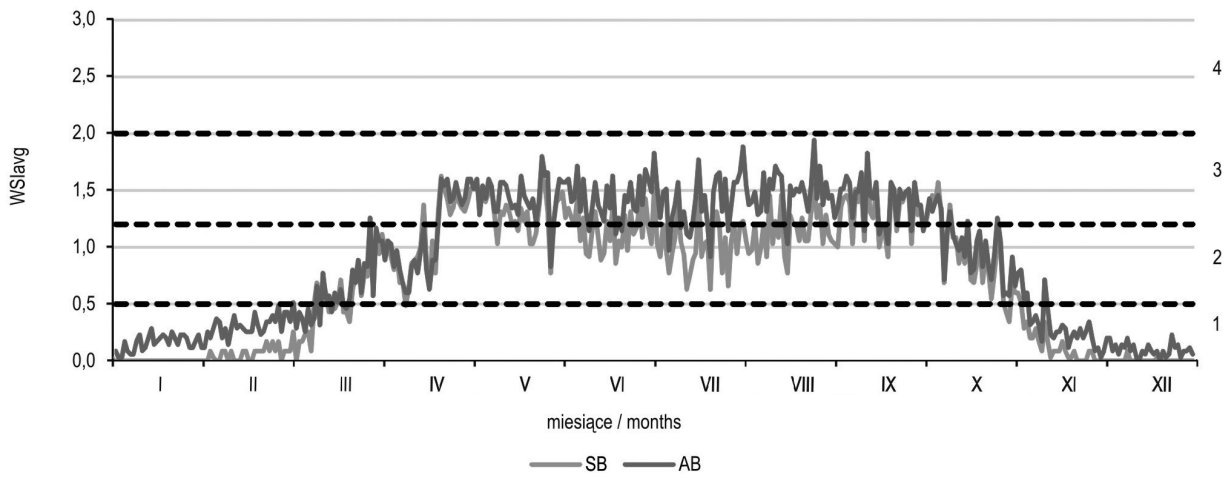

Lesko

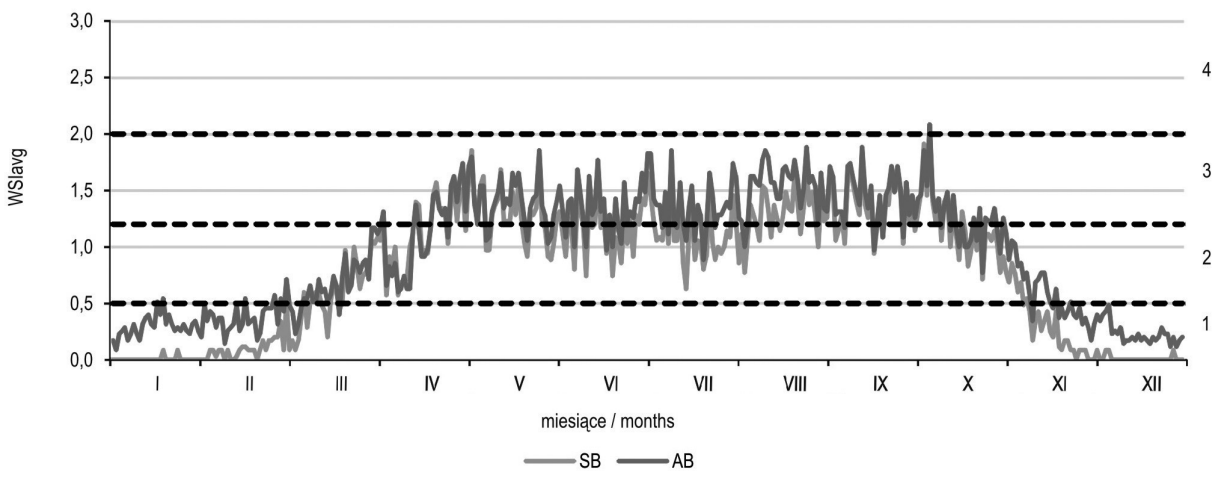




\section{Łagodne formy rekreacji ruchowej (MR)}

Zarówno w Lublinie, jak i w Białymstoku okres z pogodą sprzyjającą łagodnym formom rekreacji ruchowej (MR), takim jak spacery czy spokojne zajęcia terenowe, rozpoczynał się w lutym, a kończył w połowie października. W Lesku dni takie występowały od drugiej dekady stycznia do pierwszej dekady grudnia (ryc. 3). W skali roku dni o warunkach pogodowych korzystnych i bardzo korzystnych dla łagodnych form rekreacji ruchowej znacznie częściej występowały w Lesku (317 dni) niż w Lublinie (278 dni) i w Białymstoku (279 dni). Było to szczególnie zauważalne w styczniu i grudniu, kiedy w Lesku notowano powyżej 10 takich dni (21 dni w styczniu i 12 dni w grudniu), podczas gdy w pozostałych miastach ich liczba dochodziła do $6 \mathrm{w}$ miesiącu.

\section{Aktywne formy rekreacji ruchowej (AR)}

Warunki pogodowe korzystne i bardzo korzystne dla uprawiania aktywnych form rekreacji ruchowej (AR), takich jak: intensywne marsze, gry terenowe, turystyka piesza oraz rowerowa, występowały przez znaczną część roku. Jedynie w lipcu i w sierpniu, a sporadycznie w maju i w czerwcu notowano dni z pogodą umiarkowanie korzystną dla tych form rekreacji (ryc. 3). Wiąże się to z występowaniem, w wymienionych miesiącach wysokich wartości temperatury odczuwalnej oraz dużej liczby dni parnych, co ma niekorzystny wpływ na organizm człowieka wykonującego duży wysiłek fizyczny. W lipcu warunki umiarkowanie korzystne dla aktywnych form rekreacji ruchowej notowane były na analizowanych stacjach w liczbie: w Lublinie - 12 dni, w Lesku - 15 dni, w Białymstoku - 16 dni. W sierpniu notowano dwukrotnie mniej takich przypadków.

\section{$\leftarrow$}

Ryc. 2. Przebieg roczny średnich dobowych wartości wskaźnika oceny pogody $\left(\mathrm{WSI}_{\text {avg }}\right.$ ) dla kąpieli słonecznych (SB) i powietrznych (AB) w Polsce Wschodniej (1981-2015); 1 - pogoda niekorzystna, 2 - pogoda umiarkowanie korzystna, 3 - pogoda korzystna, 4 - pogoda bardzo korzystna

Fig. 2. Annual course of the mean daily values of the weather evaluation index (WSI ${ }_{\text {avg }}$ ) in regard to sunbathing (SB) and airbathing (AB) in Eastern Poland (1981-2015); 1 - unfavourable weather, 2 - moderately favourable weather, 3 - favourable weather, 4 - very favourable weather 
Białystok

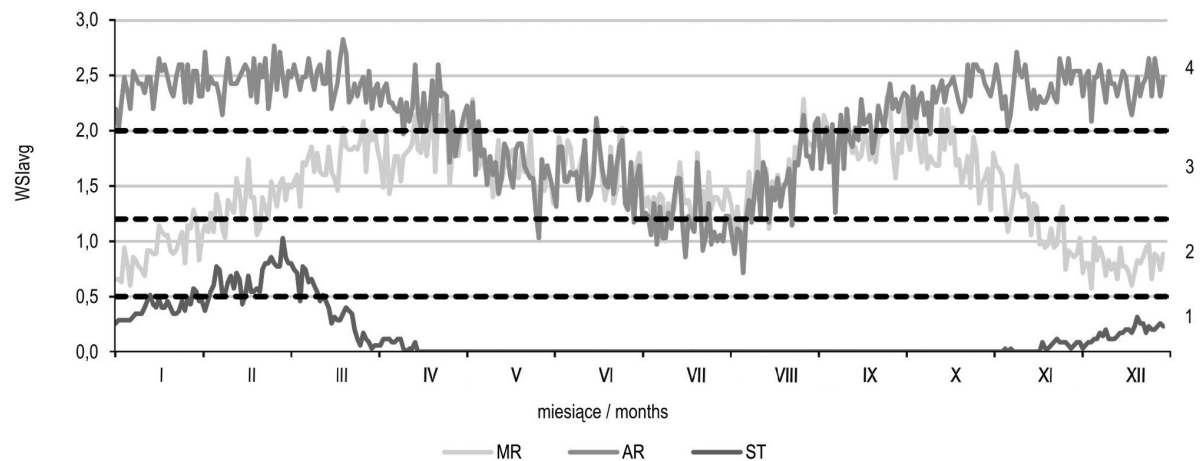

Lublin

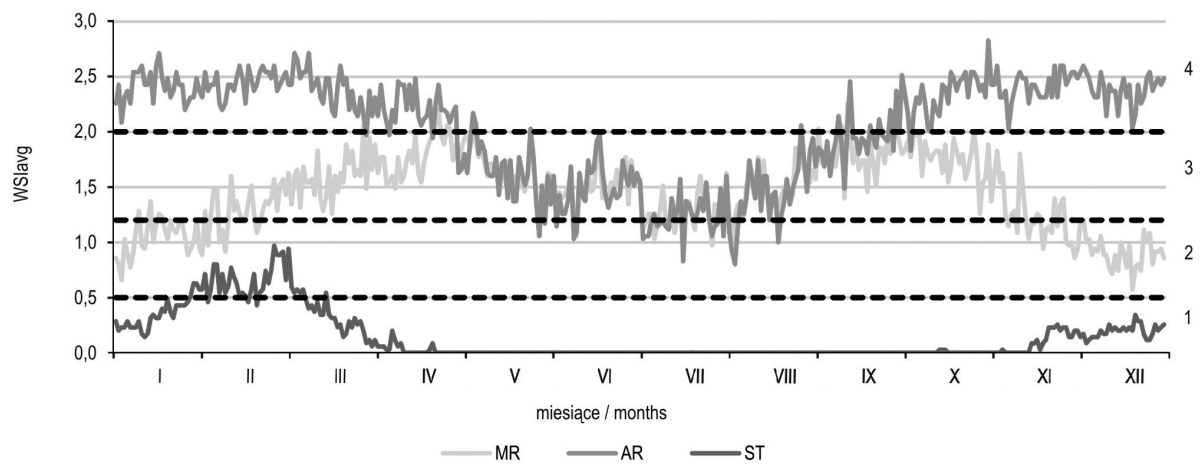

Lesko

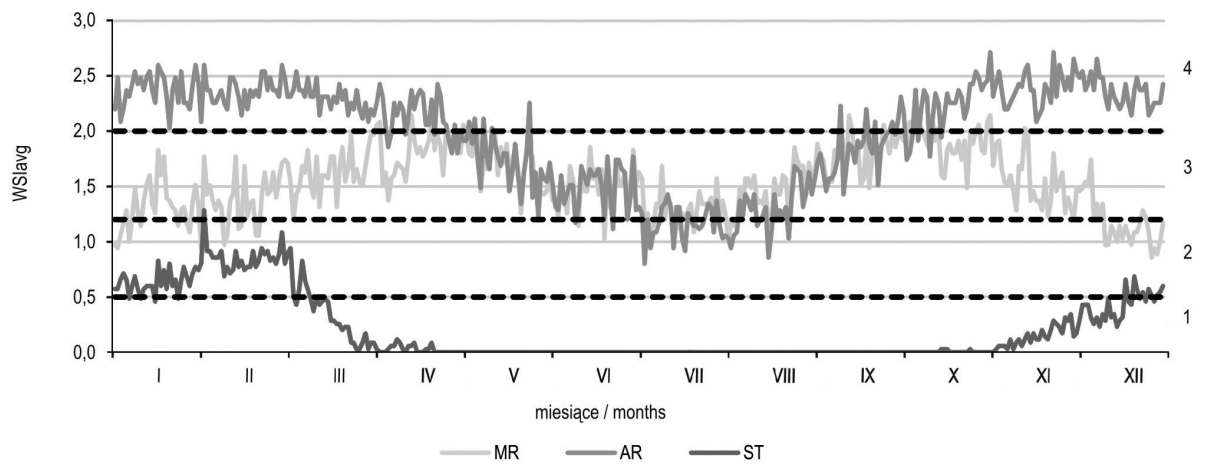




\section{Turystyka narciarska (ST)}

Z punktu widzenia możliwości uprawiania turystyki narciarskiej (ST) najkorzystniejsze warunki pogodowe notowane były w Polsce Wschodniej w lutym oraz w pierwszej dekadzie marca. W Lesku okres ten był nieco dłuższy, bo rozpoczynał się już w trzeciej dekadzie grudnia (ryc. 3). We wschodniej Polsce liczba dni o warunkach pogodowych umiarkowanie korzystnych i korzystnych do uprawiania turystyki narciarskiej wynosiła od 38 dni w Lublinie i 40 dni w Białymstoku do 71 dni w Lesku. Różnice te wynikają przede wszystkim z faktu, iż w Lesku notuje się średnio o około 10 dni więcej z pokrywą śnieżną o grubości równiej lub większej $10 \mathrm{~cm}$ niż na pozostałych stacjach. Grubość ta przyjmowana jest jako warunek konieczny do uprawiania narciarstwa i saneczkarstwa (Michna, Paczos 1971; Łobożewicz 1979; Nowosad 1980).

\section{Podsumowanie i wnioski}

Wschodnia Polska odznacza się dużą zmiennością warunków pogodowych w cyklu rocznym, co znajduje odzwierciedlenie w przydatności pogody do uprawiania wybranych form rekreacji i turystyki w terenie otwartym.

Z punktu widzenia możliwości zażywania kąpieli słonecznych w tej części kraju najkorzystniejsze warunki pogodowe występują od połowy kwietnia do połowy października. W miesiącach wiosennych, pod względem warunków pogodowych przydatnych dla tej formy aktywności, uprzywilejowany jest północno-wschodni region bioklimatyczny (III), reprezentowany przez stację w Białymstoku, natomiast w miesiącach jesiennych zaznacza się uprzywilejowanie wschodniej części regionu karpackiego (VIII), reprezentowanego przez stację w Lesku. Również od połowy kwietnia do połowy października, a w regionie karpackim (VIII) do końca

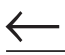

Ryc. 3. Przebieg roczny średnich dobowych wartości wskaźnika oceny pogody (WSI ${ }_{\text {avg }}$ ) dla łagodnej rekreacji ruchowej (MR), aktywnej rekreacji ruchowej (AB) oraz turystyki narciarskiej (ST) w Polsce Wschodniej (1981-2015); 1 - pogoda niekorzystna, 2 - pogoda umiarkowanie korzystna, 3 - pogoda korzytna, 4 - pogoda bardzo korzystna

Fig.3. Annual course of the mean daily values of the weather evaluation index (WSI ${ }_{\text {avg }}$ ) in regard to mild recreation (MR), active recreation (AR) and ski tourism (ST) in Eastern Poland (1981-2015); 1 - unfavourable weather, 2 - moderately favourable weather, 3 - favourable weather, 4 - very favourable weather 
października, warunki pogodowe we wschodniej części Polski sprzyjają aeroterapii. Pogoda korzystna dla łagodnych form rekreacji, takich jak spacery, występuje w regionach północno-wschodnim (III) i południowo-wschodnim (V) od lutego do połowy października. W regionie karpackim (VIII) okres ten jest dłuższy i trwa od drugiej dekady stycznia do pierwszej dekady grudnia. W regionach: nadmorskim (I) i centralnym (IV) w przebiegu rocznym także obserwuje się dwa maksima (wiosenne i jesienne), podczas których pogoda sprzyja kąpielom słonecznym, kąpielom powietrznym oraz łagodnym formom rekreacji. Natomiast w miesiącach zimowych notuje się w tych regionach warunki niekorzystne, szczególnie dla dwóch pierwszych rodzajów aktywności (Błażejczyk, Kunert 2011). Z kolei w regionie sudeckim (VII) podczas całego roku występują ograniczone warunki dla kąpieli słonecznych, okres sprzyjający kąpielom powietrznym jest zbliżony do tego, który wyznaczono dla regionu karpackiego (VIII), a łagodnym formom rekreacji sprzyjają miesiące od kwietnia do października włącznie (Miszuk 2006). Dla aktywnych form rekreacji, takich jak turystyka piesza czy rowerowa, optymalne warunki pogodowe występują przez znaczną część roku, z wyłączeniem miesięcy letnich: lipca i sierpnia, podczas których notuje się wysokie wartości temperatury odczuwalnej oraz dużą liczbę przypadków występowania parności, co ma niekorzystny wpływ na osoby wykonujące duży wysiłek fizyczny. Podobne wyniki przedstawili Błażejczyk i Kunert (2011) dla regionów nadmorskiego (I) i centralnego (IV). Z kolei badania Miszuka (2006) wskazały, że w regionie sudeckim (VII) warunki do uprawiania aktywnych form rekreacji występują nawet w miesiącach letnich. Z punktu widzenia turystyki narciarskiej najkorzystniejsze warunki pogodowe występują we wschodniej Polsce w lutym oraz w pierwszej dekadzie marca. W Lesku okres ten jest dłuższy i rozpoczyna się w drugiej połowie grudnia. Jak podali Błażejczyk i Kunert (2011), w Tatrach warunki korzystne dla uprawiania sportów zimowych trwają od początku stycznia do końca marca, a warunki umiarkowanie korzystne notuje się również w grudniu i kwietniu. Natomiast w Karkonoszach reprezentujących region sudecki (VII) okres sprzyjający uprawianiu turystyki zimowej rozpoczyna się w listopadzie i kończy w kwietniu (Miszuk 2006).

Rezultaty przedstawione $\mathrm{w}$ artykule wydają się odbiegać od powszechnie przyjętego twierdzenia, że najkorzystniejsze warunki pogodowe dla uprawiania turystyki występują w miesiącach letnich. Przyczyn tego należy szukać w założeniach metodycznych biotermiczno-meteorologicznej klasyfikacji pogody, która stanowi podstawę jakościowej oceny warunków pogodowych za pomocą wskaźnika WSI. Ocena warunków pogodowych opiera się m.in. na warunkach biometeorologicznych określanych na podstawie odczuć cieplnych człowieka, kształtowanych na skutek łącznego oddziaływania na organizm człowieka elementów meteorologicznych, takich jak m.in.: temperatura powietrza, wilgotność powietrza, prędkość wiatru, natężenie promieniowania słonecznego, a także jest związana z aktywnością fizyczną. Stąd 
też warunki pogodowe, które występują w miesiącach letnich, sprzyjają łagodnym formom aktywności, a są niekorzystne dla form intensywnej aktywności.

W umiarkowanych szerokościach geograficznych ważną rolę dla aktywności fizycznej człowieka w terenie otwartym, w tym dla uprawiania turystki, odgrywa czynnik astronomiczny, jakim jest długość dnia. Uwzględniając, że klasyfikacja, która została wykorzystana w badaniach, opiera się na warunkach biotermicznych, jakie panują w południowym terminie obserwacji, który według wielu autorów uważany jest za najbardziej reprezentatywny pod względem warunków pogodowych panujących w porze największej aktywności fizycznej człowieka (Błażejczyk 2004), należy pamiętać, że w okresie letnim potencjalny czas uprawiania turystyki ulega wydłużeniu. Jest to o tyle ważne, że w tej części roku, w godzinach porannych i wieczornych, warunki biotermiczne są znacznie korzystniejsze dla aktywnych form turystyki ze względu na łagodniejsze warunki biometeorologiczne (Wereski 2009).

Przedstawione w artykule wnioski stanowią źródło informacji, które może być przydatne zarówno podczas planowania wypoczynku we Wschodniej Polsce, jak również podczas organizowania zajęć w otwartym terenie w tej części kraju.

\section{Literatura}

Bioklima@2.6., Pakiet programu, www.igipz.pan.pl/Bioklima-zgik.html.

Błażejczyk K., 1979, Typologia pogody na potrzeby klimatoterapii, Dokumentacja Geograficzna, 2, 12-24

Błażejczyk K., 1983, Bioklimatyczna ocena i typologia uzdrowisk Polskich, Dokumentacja Geograficzna, 3, 9-85.

Błażejczyk K., 2004, Bioklimatyczne uwarunkowania rekreacji i turystyki w Polsce, Prace Geograficzne, IGiPZ PAN, 192.

Błażejczyk K., 2005, Biotermiczno-meteorologiczna klasyfikacja pogody jako narzędzie oceny warunków bioklimatycznych, [w:] Z. Babiński (red.), Środowisko præyrodnicze w badaniach geografii fizycznej, Promotio Geographica Bydgostiensia, 2, 89-127.

Błażejczyk K., Kunert A., 2011, Bioklimatycæne wwarunkowania rekreacji i turystyki w Polsce, Monografie, 13, IGiPZ PAN, Warszawa.

Fraitas C.R. de, 2001, Theory, concepts and methods in Tourism Climate Research, [w:] A. Matzarakis, C.R. de Freitas (red.), Proceedings of the First International Workshop on Climate, Tourism and Recreation, Report of a Workshop Held at Porto Carras, Neos Marmaras, Halkidiki, Greece, 5-10 October 2001. International Society of Biometeorology, 3-14, http://www. urbanclimate.net/cctr/ws/papers/01_defreitas.pdf (25.11.2016).

Howe G.F., 1925, The summer and winter weather of selected cities in North America, Monthly Weather Reviev, 10, 427-429.

Kozłowska-Szczęsna T., Błażejczyk K., Krawczyk B., 1997, Bioklimatologia cztowieka. Metody i ich zastosowanie w badaniach klimatu Polski, Monografie, 1, IGiPZ PAN, Warszawa. 
Koźmiński C., Mąkosza A., Michalska B., 2007, Bioklimatyczne warunki wypoczynku w rejonie jeziora Miedwie w pótroczu cieptym, Przegląd Naukowy Inżynieria i Kształtowanie Środowiska, 15, 3 (37), 3-37.

Łobożewicz T., 1979, Warunki rozwoju turystyki i sportu narciarskiego w Polsce w świetle badań sniegowych, Instytut Turystyki, Warszawa.

Michna E., Paczos S., 1971, Die Schneebedingungen des westlischen Bies«cæady-Gebirges in hinsicht auf Touristische und Wintersportlische anforderungen, Folia Societatis Scientiarum Lublinensis, sec. D, 11, 3-7.

Miszuk B., 2006, Ocena warunków bioklimatycznych obsæarów górskich z punktu widæenia turystyki i rekreacji pr:y wykorzystaniu biotermiczno-meteorologicznej klasyfikacji pogody na przyktadzie danych ze Szrenicy, Annales UMCS, sec. B, 61, 36, 308-319.

Miszuk B., 2008, Charakterystyka warunków bioklimatycznych Karkonoszy z punktu widzenia ró: nych form turystyki i rekreacji, Prace Geograficzne, 120, 79-91.

Miszuk B., Otop I., Strońska M., Schwarzak S., Surke M., 2016, Tourism-climate conditions and their future development in the Polish-Saxon border area, Meteorologische Zeitschrift, 25, 4, 421-434.

Nichols E.S., 1925, A classification of weather types, Monthly Weather Reviev, 10, 431-434.

Nowosad M., 1980, Ocena wybranych elementow meteorologic:nych pod kqtem potrzeb turystyki i narciarstwa na præyktadzie Præemyśla, Folia Societatis Scientiarum Lublinensis, Geogr. 2, 22, 63-68.

Piotrowicz K., 2010, Sezonowa i wieloletnia zmiennośćtypów pogody w Krakowie, Instytut Geografii i Gospodarki Przestrzennej, Uniwersytet Jagielloński, Kraków.

Sikora S., 2008, Bioklimat Wroctawia, Rozprawy Instytutu Geografii i Rozwoju Regionalnego Uniwersytetu Wrocławskiego, 5, Wrocław.

Switzer J.E., 1925, Weather types in the climate of Mexico, The Canal Zone and Cuba, Monthly Weather Reviev, 10, 434-437.

The World Travel \& Tourism Council 2016, The Economic Impact of Travel \& Tourism: 2016 Annual Update - Summary, https://www.wttc.org/-/media/files/reports/economic-impact-research/regions-2016/world2016.pdf (15.03.2017).

Wereski S., 2009, Warunki biotermicæne w Lesku w latach 2000-2005, [w:] L. Kasprzak (red.), Badania podstawowe i aplikacyjne w naukach geograficznych, Uniwersytet Adama Mickiewicza, Poznań, 51-56.

Wereski S., 2012, Przydatnośc warunków bioklimatycznych do turystyki wypoczynkowej w Solinie (1981-1998), Przegląd Geograficzny, 84 (3), 447-456.

Wereski S., Demczuk P., 2015, Ocena warunków bioklimatycznych Leska pod kątem moæiliwości uprawiania wybranych form turystyki, [w:] A. Wdowiak, A. Tucki (red.), Aspekty środowiskowo-rekreacyjne i prawne zdrowia cztowieka, Międzynarodowe Towarzystwo Wspierania i Rozwoju Technologii Medycznej, Włodawa, 212-224.

World Tourism Organization 2016, UNWTO Annual Report 2015, UNWTO, Madrid, http:// cf.cdn.unwto.org/sites/all/files/pdf/annual_report_2015_lr.pdf (15.03.2017). 
Woś A., 1996, Struktura sezonowa klimatu Polski, Bogucki Wydawnictwo Naukowe, Poznań. Woś A., 1999, Klimat Polski, Wydawnictwo Naukowe PWN, Warszawa.

Zinkiewicz W., 1953, Zagadnienia kompleksów pogodowych, Annales UMCS, sec. B, 8, 6, 312-341.

Sylwester Wereski

Uniwersytet Marii Curie-Skłodowskiej w Lublinie

Wydziat Nauk o Ziemi i Gospodarki Præestrzennej

Al. Kraśnicka 2CD, 20-718 Lublin

sylwesterwereski@umcs.pl

Mateusz Dobek

Uniwersytet Marii Curie-Sktodowskiej w Lublinie

Wydziat Nauk o Ziemi i Gospodarki Præestrzennej

Al. Kraśnicka 2CD, 20-718 Lublin

mateusz.dobek@umcs.pl

Karolina Kierklo

Instytut Meteorologii i Gospodarki Wodnej - Państwowy Instytut Badawczy

Centralne Biuro Prognoz Meteorologicznych - Zespót w Biatymstoku

ul. Ciotkowskiego 2/3, 15-245 Biatystok

karolina.kierklo@wp.pl 
